\title{
$\gamma$-Glutamyltransferase and Serum Proteins in Buffalo Calves Following Colostral Ingestion
}

\author{
Pietro Lombardi' ${ }^{1}$ Luigi Avallone', Antonio d'Angelo' and Eitan Bogin ${ }^{2}$ \\ 1 Dipartimento di Strutture, Funzioni e Tecnologie Biologiche, Università degli Studi di Napoli Federico II, \\ Napoli, Italy \\ 2 Department Biochemistry, Kimron Veterinary Institute, Tel Aviv University School of Medicine, Beit Dagan, Israel
}

Summary: Catalytic activity concentrations of $\gamma$-glutamyltransferase in blood were determined for the evaluation of colostral ingestion. $\gamma$-Glutamyltransferase levels were compared with those of total proteins, albumins and total globulins in the serum, showing good correlation at 2-3 days after birth. $\gamma$-Glutamyltransferase was determined using the Boehringer Mannheim "Reflotron" dry chemistry enzyme strips. After colostral ingestion, blood $\gamma$-glutamyltransferase increased from $35 \pm 19 \mathrm{U} / 1$ at birth to $1563 \pm 1283 \mathrm{U} / \mathrm{l}$. Electrophoretic separation of total proteins showed an increase of serum $\gamma$-globulins from $4.2 \mathrm{~g} / 1$ before ingestion to $32.9 \mathrm{~g} / \mathrm{l}$ after ingestion. The same analytes were determined in colostrum showing the major protein fraction to be $\gamma$-globulins. $\gamma$-Globulins and $\gamma$-glutamyltransferase permeate to the blood stream, and there is a good correlation between them. The enzyme $\gamma$-glutamyltransferase can be used as an equivalent for the determination of $\gamma$-globulins in the calf serum and the degree of colostral ingestion.

\section{Introduction}

Diarrhoea and other diseases in neonates of buffalo, cattle, sheep and horses are associated with insufficient circulating immunoglobulins. Prevention of diarrhoea in neonates depends to a large extent on lactogenic immunity obtained by ingestion of colostral immunoglobulins $(1,2)$. The importance of colostrum in the prevention of diarrhoea in newborn calves has been shown to be related to the protection given by the immunoglobulins in the colostrum (3-5). Buffalo calves, like most domestic animals, are born lacking circulating immunoglobulins and therefore, they must absorb maternal immunoglobulins from colostrum for passive immunity during the neonatal period $(1-5)$. These diarrhoeal diseases of neonatal calves were shown to be linked to low serum immunoglobulin concentrations, which was related to insufficient colostral ingestion, or ingestion of colostrum low in immunoglobulin concentration $(1-5)$. The newborn calf is able to absorb colostral immunoglobulins via the intestines, rapidly stopping by about 24 hours of age $(1-8)$. In dairy cattle, $25-34 \%$ of the calves fail to suckle by $6-8$ hours of age $(2,5,7)$ and consequently suffer from low serum immunoglobulins at their early critical stage of life. This impaired immunoglobulin absorption by the calves can result from either delayed or poor suckling $(1,3,5,6,8)$.

It has been shown that following colostral ingestion, serum immunoglobulins significantly increase (9). Similarly, the enzyme $\gamma$-glutamyltransferase, whose concentration in the colostrum is very high, is also absorbed into the calf serum and can serve as a biochemical test or marker for the amount and degree of colostral ingestion and absorption (9).

Colostrum represents in ruminants and equines the principal way to take maternal antibodies (1). Many diseases of neonatal calves have been shown to be related to insufficient colostral ingestion. Calves are born a-gammaglobulinaemics and absorb globulins from colostrum for passive immunity during the neonatal period (10). Buffalo colostrum, which is rich in fat and proteins (especially IgG) is poor in lactose. Calves start suckling at 2-3 hours after birth $(3,6,8)$ and the absorption of immunoglobulins lasts for 24 hours $(2-8)$. Late or inadequate colostrum intake, resulting from conditions like poor suckling drive of the calf, poor mothering behaviour and others, will result in insufficient circulating $\gamma$-globulins and immunity. It is therefore important to identify this problem as early as possible and correct it during the critical time of possible absorption. The objective of the present study was to establish the serum levels of $\gamma$-glutamyltransferase and globulins in the serum of the buffalo calf and to evaluate $\gamma$-glutamyltransferase as a marker for the determination of colostral ingestion and levels of serum globulins.

\section{Materials and Methods}

Animals

Water buffalo grown in commercial farms around Napoli were used in this study. 


\section{Samples}

Blood was taken from the jugular vein of 10 buffalo calves beforc and at 1, 3, 5, 9 and 14 days after colostral ingestion and serum was obtained. Colostrum ivas taken on the day of calving and 1 and 3 days after, the colostrum was than centrifuged at $20000 \mathrm{~g}$ for 30 minutes and the intermediate layer was withdrawn for analysis.

\section{Analysis}

$\gamma$-Glutamyltransferase, total protein, albumin and protein fractions were determined. Total protein in the serum and colostrum was determined using the biuret method (11), albumin was determined colorimetrically (12). Globulin concentrations were calculated by subtracting albumin from total protein concentrations. $\gamma$-Glutamyltransferase was measured using Boehringer Mannheim "Reflotron" (10). Protein fractions ivere determined following the electrophoretic separation using the Hydragel protein kit from SEBIA (France) and quantitated using a Preference densitometer from Ciampolini (Italy).

\section{Statistics}

Means, standard deviations and significance were determined using the general linear model (GLM) procedure of the SAS program (13).

\section{Results}

The activities of buffalo calf serum $\gamma$-glutamyltransferase and serum proteins before and at different times after colostral ingestion are shown in table 1 . Mean $\gamma$-glutamyltransferase level before colostral ingestion was 35.4 $\pm 19.1 \mathrm{U} / 1$ and increased dramatically to a mean level of $1563 \mathrm{U} / 1$ one day post partum, ( $+4410 \%)$, gradually declining to the precolostral ingestion levels $(48 \pm 40.9$ $\mathrm{U} / \mathrm{l}$ ) on day 14 . Total serum protein increased by about $50 \%$ on the first day following colostral ingestion, and slowly decreased leveling its serum concentration after the first week. Serum albumin and $\alpha$-globulins remained the same during the entire period of 14 days.

$\beta$-Globulin concentration changed slightly, increasing from means of $6.3 \pm 0.1 \mathrm{~g} / \mathrm{l}$ prior to colostral ingestion, to mean levels ranging from 7.5-8.2 g/l after colostral ingestion. A very dramatic and significant change was seen in serum $\gamma$-globulin levels changing from a mean of $4.2 \pm 0.5 \mathrm{~g} / \mathrm{l}$ prior to suckling to a peak of $32.9 \pm 1.2$ $\mathrm{g} / \mathrm{l}$ one day after colostral ingestion, and slowly decreasing to levels of $17.5 \pm 0.6 \mathrm{~g} / \mathrm{l}$ on day 14 .

Total globulin levels also increased from 17.9 to 46.2 $\mathrm{U} / 1$ slowly decreasing until $31.9 \mathrm{U} / 1$ at day 14 .

Reflecting these changes, albumin to globulin ratios in the serum changed as well, from a ratio of $1.9 \pm 0.4$ at birth prior to colostrum uptake, to $0.46 \pm 0.28$ at day 1 , slowly increasing to $0.9 \pm 0.2$ at day 14 .

$\gamma$-Glutamyltransferase, total and various protein groups in the colostrum, immedately after calving and at days 1 and 3 after calving are shown in table 2 . The colostrum immediately after calving has a very high protein

Tab. 1 Serum levels of $\gamma$-glutamyltransferase and serum proteins from buffalo calves at different days before and after colostral ingestion.

\begin{tabular}{|c|c|c|c|c|c|c|c|}
\hline \multirow[t]{2}{*}{ Analyte } & & \multicolumn{6}{|c|}{ Time of sampling (day) } \\
\hline & & Before & 1 & 3 & 5 & 9 & 14 \\
\hline$\gamma$-Glutamyltransferase & $(U / l)$ & $35 \pm 19$ & $1563 \pm 1283^{a}$ & $380 \pm 406$ & $142 \pm 149$ & $95 \pm 94$ & $48 \pm 41$ \\
\hline Total protein & $(g / l)$ & $50.1 \pm 9.0$ & $74.9 \pm 14.1$ & $69.1 \pm 11.0$ & $65.2 \pm 8.2$ & $58.4 \pm 17.0$ & $61.2 \pm 8.1$ \\
\hline Albumin & $(\mathrm{g} / \mathrm{l})$ & $32.3 \pm 0.4$ & $28.7 \pm 1.1$ & $27.9 \pm 0.6$ & $28 \pm 0.6$ & $25.9 \pm 0.6$ & $29.3 \pm 0.3$ \\
\hline Globulins & $(g / l)$ & $17.9 \pm 1.7$ & $46.2 \pm 4.4$ & $12.2 \pm 1.5$ & $35.7 \pm 3.3$ & $32.5 \pm 3.7$ & $31.9 \pm 2.9$ \\
\hline$\alpha-$ & $(\mathrm{g} / \mathrm{l})$ & $7.3 \pm 0.1$ & $5.8 \pm 0.3$ & $7.1 \pm 0.3$ & $6.6 \pm 0.1$ & $6.9 \pm 0.3$ & $7.8 \pm 0.1$ \\
\hline$\beta-$ & $(\mathrm{g} / \mathrm{l})$ & $6.3 \pm 0.1$ & $7.5 \pm 0.4^{\mathrm{a}}$ & $7.9 \pm 0.3^{a}$ & $8.2 \pm 0.3^{a}$ & $7.1 \pm 0.3^{a}$ & $7.8 \pm 0.2^{\mathrm{a}}$ \\
\hline$\gamma-$ & $(\mathrm{g} / \mathrm{l})$ & $4.2 \pm 0.5$ & $32.9 \pm 1.2^{\mathrm{a}}$ & $25.9 \pm 0.9^{\mathrm{a}}$ & $20.9 \pm 0.8^{a}$ & $15 \pm 1.1^{\mathrm{a}}$ & $17.5 \pm 0.6^{\mathrm{a}}$ \\
\hline Albumin/globulins & & $1.90 \pm 0.40$ & $0.46 \pm 0.28^{a}$ & $0.53 \pm 0.32^{\mathrm{a}}$ & $0.80 \pm 0.20^{\mathrm{a}}$ & $0.80 \pm 0.30^{\mathrm{a}}$ & $0.90 \pm 0.20^{\mathrm{a}}$ \\
\hline
\end{tabular}

$\overline{\mathrm{x}} \pm \mathrm{SD} \quad \mathrm{n}=10$

$\mathrm{a}=$ significantly different $(\mathrm{P}<0.05)$ compared to time before colostral ingestion

Tab. 2 Colostral concentrations of $\gamma$-glutamyltransferase and protein at different times after calving.

\begin{tabular}{|c|c|c|c|c|c|c|}
\hline \multirow[t]{2}{*}{ Analyte } & & \multicolumn{5}{|c|}{ Time of sampling (day) } \\
\hline & & 0 & 1 & $\Delta \%$ & 3 & $\Delta \%$ \\
\hline$\gamma$-Glutamyltransferase & $(\mathrm{U} / \mathrm{)})$ & $16621 \pm 2999$ & $7903 \pm 1605^{a}$ & -52 & $1714 \pm 338^{a}$ & -90 \\
\hline Total protein & $(g / 1)$ & $125.5 \pm 10.2$ & $39.6 \pm 3.3^{a}$ & -68 & $20.3 \pm 2.5^{a}$ & -84 \\
\hline Albumin & $(\mathrm{g} / \mathrm{l})$ & $26.2 \pm 0.2$ & $19.9 \pm 0.1^{a}$ & -24 & $10.3 \pm 0.1^{\mathrm{a}}$ & -61 \\
\hline Globulins & $(\mathrm{g} / \mathrm{l})$ & $99.1 \pm 5.2$ & $19.4 \pm 2.9^{a}$ & -81 & $10.0 \pm 1.6^{\mathrm{a}}$ & -90 \\
\hline$\alpha-$ & $(\mathrm{g} / \mathrm{l})$ & $22.4 \pm 0.2$ & $6.7 \pm 0.1^{\mathrm{a}}$ & -70 & $2.9 \pm 0.1^{\mathrm{a}}$ & -87 \\
\hline$\beta-$ & $(\mathrm{g} / \mathrm{l})$ & $5.0 \pm 0.1$ & $3.3 \pm 0.1^{\mathrm{a}}$ & -34 & $4.6 \pm 0.1^{a}$ & -50 \\
\hline$\gamma-$ & $(\mathrm{g} / \mathrm{l})$ & $71.7 \pm 0.4$ & $9.4 \pm 0.1^{\mathrm{a}}$ & -87 & $15.0 \pm 1.1^{\mathrm{a}}$ & -94 \\
\hline Albumin/globulins & & $0.26 \pm 0.04$ & $1.03 \pm 0.17^{a}$ & -75 & $1.04 \pm 0.12^{\mathrm{a}}$ & -75 \\
\hline
\end{tabular}

$\overline{\mathrm{x}} \pm \mathrm{SD} \quad \mathrm{n}=10$

a = significantly different $(P<0.05)$ compared to time before colostral ingestion 
Tab. 3 Correlation coefficients and degree of significance between serum levels of $\gamma$-glutamyltransferase, total protein and globulins.

\begin{tabular}{|c|c|c|c|c|}
\hline \multirow{2}{*}{$\begin{array}{l}\text { Time after } \\
\text { colostral intake } \\
\text { (days) }\end{array}$} & \multicolumn{2}{|c|}{ Total protein } & \multicolumn{2}{|c|}{ Globulins } \\
\hline & $\mathbf{r}$ & $\mathrm{p}$ & $\mathbf{r}$ & $p$ \\
\hline 0 & 0.27 & 0.44 & 0.08 & 0.82 \\
\hline 1 & 0.53 & 0.11 & 0.75 & 0.01 \\
\hline 3 & 0.28 & 0.42 & 0.76 & 0.01 \\
\hline 5 & 0.53 & 0.01 & 0.54 & 0.01 \\
\hline 9 & 0.30 & 0.38 & 0.36 & 0.29 \\
\hline 14 & 0.50 & 0.13 & 0.16 & 0.65 \\
\hline
\end{tabular}

$\mathrm{n}=10$

content $(125.5 \pm 10.2 \mathrm{~g} / \mathrm{l})$, but the concentration decreases rapidly to less than $20 \%$ of its initial concentration on day $3(20.3 \pm 2.5 \mathrm{~g} / \mathrm{l})$. Greater decreases were seen in the colostral levels of the enzyme $\gamma$-glutamyltransferase (90\%), $\alpha$-globulins (about $70 \%$ ) and $\gamma$ globulins (94\%).

Reflecting these changes, the albumin to globulin ratios also changed from $0.26 \pm 0.04$ to $1.04 \pm 0.12$.

The correlation coefficients between serum $\gamma$-glutamyltransferase and serum proteins, and the degree of significance are shown in table 3 . High and significant correlations between $\gamma$-glutamyltransferase and globulins were seen on days 1 and 3 , decreasing on the following days.

The pattern and relative distributions of primary buffalo calf serum before and after colostral ingestion and primary colostral proteins are shown in figures 1 and 2 . As seen, the most striking change in the calf serum composition following colostral ingestion was the large increase of the $\gamma$-globulin fraction (fig. 1). Studying the protein fractions in the colostrum reveals that $\gamma$-globulin is the major protein component, consisting of $54.2 \%$ of total proteins (fig. 2).

The results seen with the buffalo in this study show a very large resemblance to those seen with dairy cattle (9), strongly suggesting that in the buffalo as well, the enzyme $\gamma$-glutamyltransferase can serve as marker for the degree of colostral ingestion by the calf. Of interest is the observation about the rapid rate of decrease of the $\gamma$-globulins in the colostrum shortly after calving, paralleling the ability of the calf to absorb large molecular mass proteins from the intestines to the blood. The $\gamma$-globulins, which are produced by the cow, and transferred to the udder can be absorbed by the calf only during the first day of life. It is likely that because the transfer of globulins is not possible one day after calving, the production is discontinued.

The reason for the high levels of the enzyme $\gamma$-glutamyltransferase in the colostrum is not clear. It could be that the very high enzyme content is related to the high protein synthesis. Its function if any in the calf serum during the first day of life is not known.

The enzyme originates from the active epithelial cells in the mammary gland, and is probably involved in the secretory process and milk production in the udder.

Of interest is the observation that in the first day following colostral ingestion a different pattern was seen for the various serum proteins. While $\gamma$-globulin levels significantly increased, $\beta$-globulin concentration did not change and $\alpha$-globulin and albumin slightly decreased. Closed observation of the pattern of change in serum protein concentrations on day one after ingestion, reveals a negative relationship between absorption rate and the electrical charges of the molecules, with those being the least negatively charged ( $\gamma$-globulin) permeating at a greater rate than the molecules with increasing negative charges ( $\beta$-globulin, $\alpha$-globulin and albumin, respectively). This suggests that there may be a mechanism of transfer of these proteins into the blood based on the electric charge of the molecule. Following the change in the conditions in the calf's digestive system, such as $\mathrm{pH}$, the permeability to the blood changes as well. These changes in $\mathrm{pH}$ could be caused by the acidification process in the stomach, making the conditions more favorable for digestion but not for permeation.

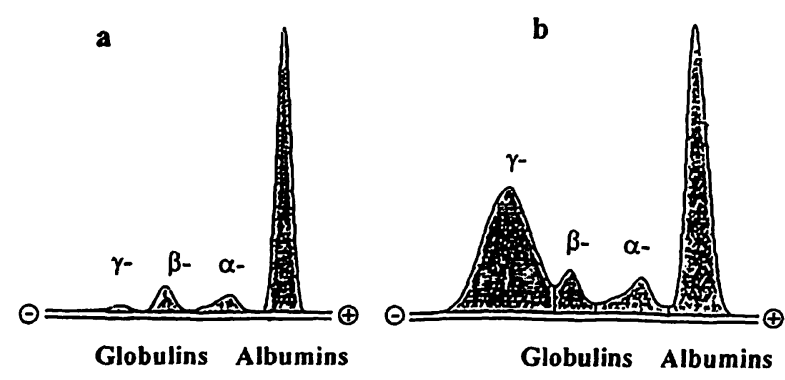

Fig. 1 Electrophoretically separated calf serum proteins before (a) and after (b) colostral ingestion.

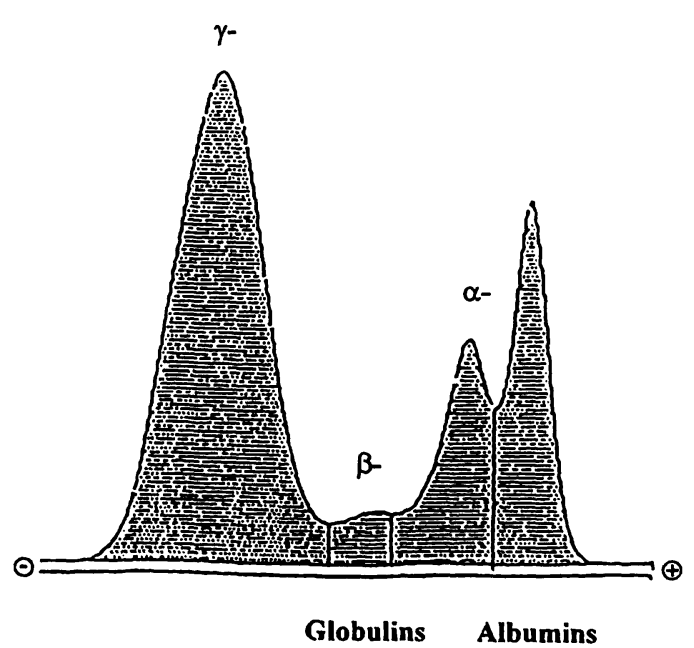

Fig. 2 Elcctrophoretically separated buffalo colostrum proteins. 


\section{References}

1. Hafez ESE. Biologia a tecnologia della riproduzione nelle specie animali di interesse. Zootecnico Editoriale Grasso, 1984.

2. Petrie L. Maximizing the absorption of colostral immunoglobulins in the newborn dairy calf. Vet Record 1984; 114:157-63.

3. Stott GH, Marks DB, Menettee BE, Nighengale GT. Colostral immunoglobulin transfer in calves. I Period of absorption. J Dairy Sci 1979, 62:1632-8.

4. Ishikawa $\mathrm{H}$, Konishi $\mathrm{Y}$. Changes in serum immunoglobulin levels in suckled calves from birth to five weeks. Vet Record 1982; 94:367-70.

5. Logan EF, McBeath OG, Lowman BG. Quantitative studies on serum immunoglobulin levels in suckled calves from birth to five weeks. Vet Record 1974; 94:367-70.

6. Matte JJ, Girrard CL, Seaone JR, Braisson GJ. Absorption of colostral immunoglobulin $G$ in the newbom dairy calf. J Dairy Sci 1982; 65:1765-70.

7. Bush LJ, Staley TE. Absorption of colostral immunoglobulins in newborn calves. J Dairy Sci 1980; 63:672-80.

8. Stott GH, Marx DB, Menettee BE, Nightengale GT. Colostral immunoglobulin transfer in calves. II The rate of absorption. J Dairy Sci 1979; 62:1766-73.
9. Bogin E, Avidar Y, Shenkler S, Israeli BA, Spiegel N, Cohen R. A rapid field test for the determination of cholostral ingestion by calves, based on $\gamma$-glutamyltransferase. Eur $\mathrm{J}$ Clin Chem Clin Biochem 1993; 31:695-9.

10. Boehringer-Mannheim GmbH Reflotron, Manual. Germany, 1989.

11. Gornall AG, Bardawill CJH, David DD. Determination of serum proteins by means of biuret reaction. J Biol Chem 1949; 177:751-66.

12. Doumas BT, Biggs HG. Determination of serum albumin. Standard methods of clinical chemistry. New York: Academic Press, 1972.

13. SAS Institute Inc. SAS user's guide: 'statistics, SAS Institute Inc. Carry, NC, NY, 1985.

\section{Received June 17/September 26, 1996}

Corresponding author: Professor Dr. Eitan Bogin, Department of Biochemistry, Kimron Veterinary Institute, Tel Aviv University School of Medicine, P. O. Box 12, Beit-Dagan 50250, Israel 